\title{
140 Years of the Leçons sur l'histologie du système nerveux: the pioneering description of the nodes of Ranvier
}

\author{
140 Anos da Leçons sur l'histologie du système nerveux: a descrição pioneira dos nodos \\ de Ranvier \\ Otto Jesus HERNANDEZ FUSTES ${ }^{1}$, Cláudia Suemi Kamoi KAY'1, Paulo José LORENZONI¹, Renata Dal-Pra \\ DUCCl'1, Jean-Gaël BARBARA², Lineu Cesar WERNECK'1 , Rosana Herminia SCOLA
}

\begin{abstract}
This paper reviews aspects of the life and work of Professor Louis Ranvier 140 years after the publication of Leçons sur l'histologie du système nerveux, published in 1878, and shows the importance of the histological description of myelinated fibers of the nodes of Ranvier.

Keywords: Histology; peripheral nervous system diseases; Ranvier's nodes.

\section{RESUMO}

Os autores apresentam uma revisão sobre aspectos da vida e obra do Professor Louis Ranvier 140 anos após a publicação de seu livro Leçons sur l'histologie du système nerveux publicado em 1878 e mostra a importância da descrição histológica nas fibras mielínicas dos nodos de Ranvier.
\end{abstract}

Palavras-chave: Histologia; doenças do sistema nervoso periférico; nós neurofibrosos.

In recent years, significant advances have been made in the knowledge of the pathophysiology of immune-mediated neuropathies, especially in the role of the nodal region, giving rise to the so-called nodopathies ${ }^{1}$.

These nodopathies may point directly to the site of nerve injury; circumventing the apparent paradox that axonal lesions may be reversible and have a good prognosis. Some patients may be classified as having a demyelinating neuropathy, and others as having an axonal neuropathy; the potential reversibility in neuropathies traditionally thought to be characterized only by axonal degeneration opens a therapeutic window and stimulates research for timely targeted treatments ${ }^{1}$.

This year marks 140 years on from the first description of the nodal region by French physician, physiologist and anatomist, Louis Ranvier, a student of Claude Bernard.

\section{LOUIS ANTOINE RANVIER}

Louis Antoine Ranvier was born in Lyon, in 1835, where he took up medical studies at the École Préparatoire de Médecine et de Pharmacie, then moved to Paris in 1860, after he succeeded in the highly competitive examination for internship at Parisian hospitals. During his medical training, Ranvier became acquainted with normal and pathological anatomy, and soon turned to microscopy as a means for further studies on tissues ${ }^{2,3,4,5}$.

Between 1860 and 1865, Cornil and Ranvier devoted much of their time to microscopy. Besides observing tumors and other pathological tissues, Ranvier focused on bone preparations, which led him to study cartilage and bone lesions for his medical thesis. By 1865, they had started collaborating on epithelial tumors.

\footnotetext{
${ }^{1}$ Universidade Federal do Paraná, Hospital de Clínicas, Departamento de Clínica Médica, Serviço de Neurologia, Serviço de Doenças Neuromusculares, Curitiba PR, Brasil.

${ }^{2}$ Neuroscience Paris Seine, Sorbonne Universités, UPMC Université Paris 06, Institut de biologie Paris-Seine, Paris, França.

Otto Jesus Hernández Fustes iD https://orcid.org/0000-0003-0778-5376; Cláudia Suemi Kamoi Kay (iD) https://orcid.org/0000-0003-0173-0809; Paulo José Lorenzoni iD https://orcid.org/0000-0002-4457-7771; Renata Dal-Prá Ducci iD https://orcid.org/0000-0002-1673-5074; Jean-Gaël Barbara iD https://orcid.org/0000-0002-2778-9369; Lineu Cesar Werneck iD https://orcid.org/0000-0003-1921-1038; Rosana Herminia Scola iD https://orcid. org/0000-0002-3957-5317

Correspondence: Otto J.H. Fustes; Hospital de Clínicas da UFPR; Rua General Carneiro, 181; 80060-900 Curitiba PR; E-mail: otto.fustes@hc.ufpr.br Conflict of interest: There is no conflict of interest to declare.

Received 16 November 2018; Received in final form 24 June 2019; Accepted 28 June 2019.
} 
From 1866 to 1867, Cornil and Ranvier's one-semester course in microscopy had no equivalent in France. The course was published in three parts, as an authoritative manual, two years later. It was translated into English, with notes and additions both in England and the United States. It represented a well-written and useful modern textbook for medical students interested in normal and pathological histology. Their collaboration ended when Ranvier agreed to join Claude Bernard at the Collège de France.

Ranvier was influenced by Virchow's extension of cellular theory to pathology. In Ranvier's introductions to studies on cartilage and bone, Virchow's observations were emphasized. While Cornil further investigated pathological tissues, Ranvier focused on normal histology. He was not only concerned with cell theory, but also, as a student of Bernard, with the development, nutrition and functions of normal tissues.

\section{THE NODE}

In 1853, Virchow used the term myelin to refer to the large sheath mass involving some axons. The term oligodendrocyte was suggested by Pío del Río-Hortega, who observed that this cell had a shorter length and less branching when compared with astrocytes and also suggested that, like the neurolemmocyte, it formed myelin, a theory proven years later by electron microscopy ${ }^{6}$.

In 1871, from his laboratory in the College of Paris, Ranvier went further, looking for new techniques to visualize "invisible" structures and to be able to explain questions of physiological type ${ }^{7}$. The sciatic nerve of frogs, dissociated (nerve trunks) and fixed in osmic acid, showed visible strangulations that had already been referred to in other works, but it was Ranvier who described them for the first time. We refer to the "Ranvier nodes" as the narrowing observed in the modulated nerve fibers, at intervals of $1 \mathrm{~mm}$, due to the interruption of myelination. But for Ranvier, histology did not end with technique and description, but had also to give way to the study of functions.

In 1878, he wrote in his Lessons on Histology of the Nervous System (Figure 1) that myelin acted as an electrical insulation, and was interrupted at various points along the axon $^{8}$. These interruptions were therefore called the nodes of Ranvier (Figure 2). The importance of these nodes was unraveled by two research groups during the 1940s: Tasaki and Takeuchi, in 19419' ; and Huxley and Stämpfli in $1949^{10}$.

In myelinated fibers, depolarization (due to ion exchange) can only occur in the nodes of Ranvier, where the dielectric envelope (myelin) is interrupted. This mode of impulse propagation in myelinated fibers was deciphered in 1925, by Lillie ${ }^{11}$.

In 1897, Ranvier and Balbiani founded the Archives d'anatomie microscopique, the first French journal devoted exclusively to microscopic studies.

Between 1875 and 1890, people like Malassez, Louis de Sinéty, Maurice Debove, Renaut, Babinski, William Nicati,

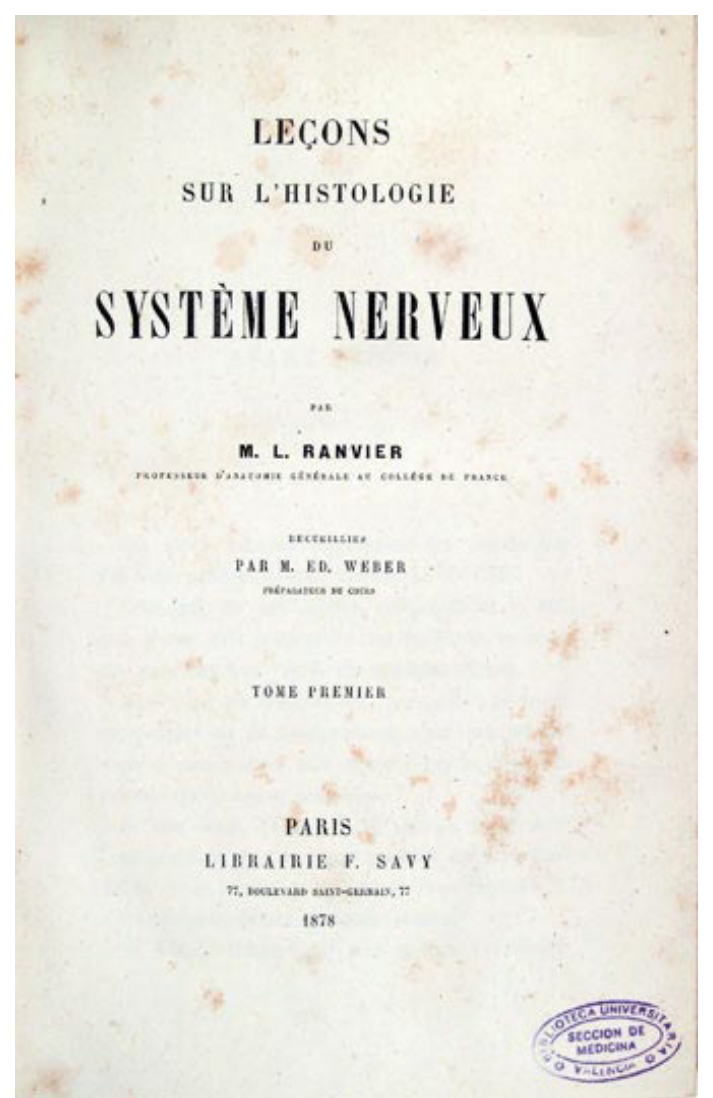

Figure 1. Cover of the book Leçons sur l'histologie du système nerveux. Paris, 1878.

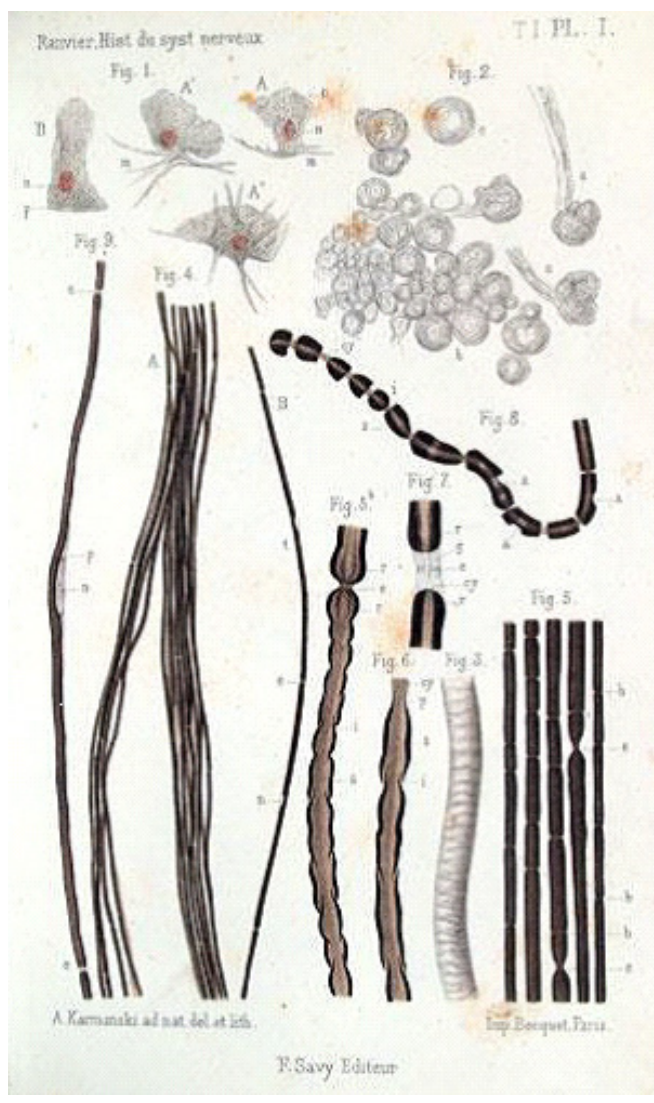

Figure 2. A page from Leçons sur l'histologie du système nerveux. Paris, 1878. 
Albarran and Suchard, among others trained in Ranvier's laboratory.

In 1900, Ranvier was isolated from the scientific community and retired to Thélys, where he spent the following 22 years on activities unrelated to science. Ranvier died in Vendranges, Loire, on 22 March 1922, leaving a legacy that transcended time, still serving as an inspiration today.
Ranvier's contributions were emphasized by Ramon y Cajal: "In my systematic explorations through the realms of microscopic anatomy [...] I examined [the Nervous System] eagerly in various animals, guided by the books of Meynert, Huguenin, Luys, Schwalbe and, above all, the incomparable works of Ranvier, of whose ingenious technique I made use with conscientious determination" ${ }^{12}$.

\section{References}

1. Uncini A, Kuwabara S. Nodopathies of the peripheral nerve: an emerging concept. J Neurol Neurosurg Psychiatry. 2015 Nov;86(11):1186-95. https://doi.org/10.1136/jnnp-2014-310097

2. Barbara JG. History of neuroscience: Louis Ranvier (1835-1922). IBRO History of Neuroscience. 2007 [cited 2018 Mar 10]. Available from: http://ibro.org/wp-content/uploads/2018/07/Ranvier-Louis. pdf

3. Barbara JG. Biological generality and general anatomy from Xavier Bichat to Louis Antoine Ranvier. In: Chemla K, Chorlay R, Rabouin D, editors. The Oxford handbook of generality in mathematics and the sciences. Oxford: Oxford UP; 2016. p. 359-84

4. Barbara JG. Louis Ranvier (1835-1922): the contribution of microscopy to physiology and the renewal of French general anatomy. J Hist Neurosci. 2007 Oct-Dec;16(4):413-31. https://doi. org/10.1080/09647040600685503

5. Barbara JG. Louis Ranvier, l'anatomie générale microscopique et les recherches sur les cellules nerveuses. In: Barbara JG, Clarac F, editors. Le cerveau au microscope: la neuroanatomie française aux XIXe et XXe siècles. Paris: Hermann; 2017. p. 71-88.
6. Mendes PB, Melo SR. Origem e desenvolvimento da mielina no sistema nervoso central: um estudo de revisão. Rev Saúde Pesq. 2011 Jan-Abr.;4(1):93-9.

7. Ranvier L. Contributions à l'histologie et à la physiologie des nerfs périphériques. Comptes Rendus de l'Académie des Sciences. 1871;73:1168-71.

8. Ranvier ML. Leçons sur l'histologie du système nerveux. Paris: Librairie F. Savy; 1878

9. Tasaki I, Takeuchi T. Der am Ranvierschen Knoten entstehende Aktionsstrom und seine Bedeutung für die Erregungsleitung. Pflügers Archiv ges Physiol. 1941;244:696-711.

10. Huxley AF, Stämpfli R. Evidence for saltatory conduction in peripheral myelinated nerve fibers. J Physiol. 1949;108(3):315-39. https://doi.org/10.1113/jphysiol.1949.sp004335

11. Lillie RS. Factors affecting transmission and recovery in the passive iron nerve model. J Gen Physiol. 1925 Mar;7(4):473-507. https://doi.org/10.1085/jgp.7.4.473

12. Ramón y Cajal S. Recuerdos de mi vida, historia de mi labor científica. Madrid: Aianza Universidade; 1995. 